\title{
Michał Zawadzki
}

Jönköping International Business School

Otrzymano/Received: 5.01.2020

Zaakceptowano/Accepted: 20.02.2020

Opublikowano/Published: 31.03.2020

\section{Recenzja książki}

Barbara Czarniawska, Badacz w terenie, pisarz przy biurku. Jak powstaja nauki społeczne?, Wydawnictwo SIZ, Łódź 2018, 214 ss., ISBN: 978-83$-65766-20-5$

Barbara Czarniawska, profesor w göteborskim Instytucie Badawczym, to najczęściej cytowana i najbardziej znana na świecie polska badaczka zarządzania. Prace współtwórczyni przełomu narracyjnego w naukach społecznych rzadko jednak są publikowane i tłumaczone w Polsce (ostatnią książką była wydana przez Sedno w 2014 roku Zmiana kadru. Jak zarzadzano Warszawa w okresie przemian), co wynikać może z bardziej ogólnego problemu braku przyswajalności światowych, humanistycznych tendencji w polskich naukach zarządzania. Recenzowane dzieło bez wątpienia wypada zatem nazwać sporym wydarzeniem na polskim rynku publikacji akademickich, ale przede wszystkim ze względu na jego istotny wkład w rozwój świadomości metodologicznej w badaniach naukowych.

Recenzowana książka to tłumaczenie autorskie Social Science Research. From Field to Desk z 2014 roku (Sage) i jest świetnie napisanym kompendium wiedzy o meandrach metodologii jakościowej. Wyróżnia się na tle innych publikacji o podobnej tematyce przystępnym językiem, ciekawymi przypadkami z terenu, zachęcającymi do dalszej pracy ćwiczeniami oraz listą lektur do samodzielnego zgłębiania. Nie jest to zbiór uniwersalnych zasad prowadzenia badań (jak zaznacza autorka, takie w nauce nie istnieją), lecz pogłębiona refleksja nad nimi, która czytelnikowi pozwala lepiej wybrać i zrozumieć własną ścieżkę metodologiczną. 
Książka składa się z czternastu rozdziałów, które śledzą metodologię badań od wyboru zjawiska i przeglądu literatury, poprzez projektowanie badań i zbieranie materiału w terenie, aż po spisanie wyników. Jak pisze Czarniawska: „prowadzić badania to znaczy nieustannie podejmować decyzje o charakterze moralnym, często samotnie i pod presją czasu" (s. 10). Wypada zgodzić się z autorką: bycie badaczem nie jest łatwe we współczesnych kulturach akademickich nastawionych na szybkość publikacji, często kosztem jakości badań. Trudno jest też dzisiaj, w kulturze sukcesu i presji na akademicką rywalizację, prezentować postawę wątpiącego myśliciela - tymczasem autorka ostrzega, że „kiedy rozumie się wszystko, nie ma nic do wyjaśniania” (s. 69) i badanie kończy się fiaskiem. Tym bardziej warto zatrzymać się na chwilę i pomedytować nad rozważaniami światowego eksperta w zakresie metodologii.

Autorka kładzie spory nacisk na omówienie teorii ugruntowanej charakteryzującej się abdukcją, a więc logiką odkrywania i formułowania nowych teorii. Taki typ prowadzenia badań nadal stanowi novum w polskich naukach zarządzania, tym bardziej cieszy popularyzacja tej metodologii. Podobać się może również umiejętne odczarowywanie powszechnych błędów w projektowaniu badań, takich jak mylenie przypadku z terenem - studium przypadku to „studium występowania badanego zjawiska" (s. 35), a nie studium danej organizacji. Dalej istotne jest podkreślenie, że wywiad (któremu autorka poświęca sporo miejsca) to pewna forma dialogu między rozmówcami, a stosowanie w nim pytań zamkniętych czyni z niego ustną ankietę. Ciekawe są również spostrzeżenia autorki - rozwinięte za Davidem Silvermanem na temat samego procesu pisania. Narrację, jak zauważa Czarniawska, najlepiej pisać... od końca do początku, chwytając za pióro dopiero po zakończeniu badań.

Oprócz omówienia popularnych technik badawczych, takich jak wywiad, obserwacja czy analiza tekstów, autorka prowadzi refleksję nad shadowingiem („chodzeniem jak cień") - postawą i techniką badawczą polegającą na śledzeniu danej osoby (ale też przedmiotów, jak dowiadujemy się w rozdziale szóstym), opartą na niewspółobecności (inny człowiek, obecny gdzie indziej, dlatego warto nawiązać z nim dialog) i poszanowaniu różnic. Nie zawsze jest to łatwe zadanie. Jak pisze autorka, amerykański profesor antropologii Harry Wolcott postanowił kiedyś przerwać badania z udziałem pewnego dyrektora, ponieważ... „ten nosił białe skarpetki do ciemnego garnituru i wyrażał się lekceważąco o swoich uczniach" (s. 71). Może gdyby Wolcott posłuchał rad Czarniawskiej, że „obserwator nigdy nie będzie miał lepszej wiedzy niż aktorzy” (s. 65) i że „maska jest bardziej interesująca niż «autentyczne zachowanie»", zmieniłby swoje nastawienie i kontynuował shadowing?

Jeden fragment omawianej książki wzbudził moje szczególne zainteresowanie, a mianowicie stwierdzenie autorki w rozdziale zatytułowanym Jak zostać pisarzem (lub pisarką), że „opowieści autograficzne przechrzczone zostały na «autoetnografie», co jest oksymoronem, chyba że osoba pisząca cierpi na zespół mnogiej osobowości i traktuje siebie samą jako "plemię» (z greckiego ethnos)" (s. 156). Jako miłośnik pisania autoetnografii muszę przyznać, że uwaga ta zmotywowała mnie do dalszych 
poszukiwań literaturowych. Wydaje mi się, że o ile zwolennicy autoetnografii ewokatywnej (opartej na prezentacji personalnych emocji i doświadczeń) mogliby pomyśleć nad zmianą terminu na „autografię”, o tyle piszący autoetnografie w duchu analitycznym mieliby z tym problem. Analityczna tradycja, jak stwierdza jej propagator Leon Anderson, wymaga przecież bycia aktywnym członkiem jakiejś grupy ludzi: bada się swoje (auto) usytuowanie w kontekście społecznym przez pryzmat relacji $\mathrm{z}$ innymi osobami (etno), wykorzystując w tym celu teorie naukowe (grafia). Mało tego, autoetnografia to metoda silnie uwikłana w politykę emancypacji, pozwalająca na usłyszenie głosów pokrzywdzonych i uciszonych członków organizacji - zdaje się jednak, że Barbara Czarniawska niezbyt entuzjastycznie patrzy na emancypacyjny walor badań społecznych w ogóle (zob. s. 161). Mimo to badaczka podaje ciekawe argumenty, które pozwalają na krytyczną autorefleksję nad własną praktyką pisania osobistych narracji.

Recenzowana praca na pewno pomaga podnieść jakość prowadzonych badań naukowych, o pomoc warto zwrócić się również do innych osób, bo „może być również i tak, że Twój promotor lub szef naprawdę wie lepiej, bez względu na to, jak bardzo to wydaje się nieprawdopodobne" (s. 14). Specyficzny humor Barbary Czarniawskiej to ogromna zaleta tej książki. Niełatwy temat metodologii staje się dzięki temu o wiele bardziej przystępny. Inną wartością publikacji są odwołania do światowej literatury z zakresu metodologii, co pozwala na śledzenie najważniejszych tendencji w nauce. Nie można nie wspomnieć o dobrze dobranych pytaniach na końcu każdego rozdziału oraz rekomendacjach dodatkowych lektur.

Jak pisze autorka, „nawet dobrze napisany tekst może przekonywać lub nie w zależności od miejsca i czasu, w jakich będzie czytany. Ale obowiązkiem badacza jest starać się przekonywać - i dobrze pisać" (s. 171). Mnie autorka przekonuje za każdym razem, kiedy sięgam po tę pozycję w trakcie prowadzenia badań jakościowych. 